\title{
SAUDI ARABIA, THE SOVIET UNION, AND MODERN ISLAM
}

\author{
Sean Foley*
}

\begin{abstract}
This paper examines Saudi-Soviet diplomacy in the interwar period, which has received little scholarly coverage but has had an important impact on the Middle East and the Muslim World. In the 1920s and the 1930s, Saudi Arabia and the Soviet Union cooperated closely in a number of areas, and Western governments recognised that an alliance would have transformed politics in the Middle East. The failure of the diplomatic relationship to last was a missed opportunity for both states and for the wider Muslim world. Not only did it limit Soviet diplomacy in the Arab World and cement the US-Saudi alliance, but it also cut off Soviet Muslims from Arabia. After the Soviet Union collapsed, the legacy Saudi-Soviet relations in the interwar period remained important. Al-Qaeda used Riyadh's historic ties with Washington to justify its violence, while millions of Muslims in the former Soviet Union re-embraced their faith and forged closer ties with Saudi Arabia than ever before.
\end{abstract}

\section{Introduction}

On 29 May 1932 a battalion of Soviet cavalry and one of Soviet infantry stood at attention for an unusual visitor to Moscow's Belorussian-Baltic railway station: Prince Faysal of the Kingdom of Saudi Arabia. Wearing a gold-braided thob, gallabia, and burnoose but with Western shoes, the twenty-six-year-old prince was only the second such personage to visit the Soviet capital since the fall of the Czar in 1917. ${ }^{1}$ Senior Soviet officials, including first deputy foreign minister Nikolai Krestinsky, met him and his delegation at the train station and joined the Soviet officials who had met the Saudi Prince's train when it crossed the Polish-Soviet border. ${ }^{2}$ As the prince walked along an exquisite carpet past saluting soldiers, large crowds gathered to see him and bands alternated playing the Hijaz's national anthem and the Internationale. Flags of the Soviet Union with the yellow hammer and sickle and that of Saudi Arabia, emblazoned with the Islamic declaration of faith, the shahādah, adorned the station. A large sign in Arabic read "Ahlan Wa Sahlan."

Over the next week, Faysal and his party met with the Soviet elite and diplomatic corps and attended a large reception and two plays at the Bolshoi Theatre. They also visited the Red Army House, a horse show, the Military Aviation Academy, and the AMO automobile factory. They travelled to Leningrad, where they were warmly received before travelling to Istanbul via Odessa. The 
young prince marvelled at the rapid development of Soviet industries and its modern technology, including its oil industry. He cabled home from the steamer Pravda on the Caspian Sea that he loved the natural beauty of the Transcaucasian Republics and "had been especially impressed by the oil derricks and the techniques of getting oil" in Baku. ${ }^{4}$

These types of comments (and the visit) worried American and European officials. They viewed the Soviets as a competitor in Arabia and the wider Middle East. Not only did thousands of subjects from Western colonies make the annual Hajj pilgrimage, but Saudi Arabia was close to Iran, Iraq, and other Middle East nations where Britain had vast economic and strategic interests. France, Italy, and Holland had thousands of Muslims in their overseas colonies, some of which were close to Arabia. (Pilgrims from the Dutch East Indies, whose population was increasingly demanding full independence, were usually the largest component of the annual Hajj pilgrimage.) For its part, Washington had just established formal diplomatic ties with King Abdulaziz's government in $1931^{5}$ and had begun to understand the enormous economic potential of his state after years of invitations by the King for prominent Americans to visit his kingdom. ${ }^{6}$

Western fears about the Soviet position in Arabia, however, were greatly exaggerated. Although the Saudi government was effectively broke, it refused Soviet terms to lend $£ 1$ million and write off Saudi debts to Moscow, lift its embargo on Soviet products and sign commercial and friendship treaties. ${ }^{7}$ Diplomatic relations never recovered from this setback and they were suspended in May 1939. Riyadh's ties with Moscow did not resume until the early 1990s, shortly after Iraq's invasion of Kuwait. ${ }^{8}$

The limited duration of Saudi-Soviet diplomatic ties in the 1920s and 1930s, however, does not diminish the importance of the relationship, which has received little coverage in the scholarship on the history of the Soviet Union, the Middle East, or Islamic World generally. ${ }^{9}$ In the 1920s, the two sides cooperated closely at times, and Western nations recognised that an alliance would have transformed the politics of the region and Asia. The failure of Saudi Arabia's diplomatic relationship with the Soviet Union was a missed opportunity for both nations and for the Muslim world generally. Not only did it limit Soviet diplomacy in the Middle East and pave the way for the rise of the U.S.-Saudi strategic alliance, but it also cut millions of Muslims in the Soviet Union off from the rest of the Islamic World. Few Soviet Muslims were allowed to go on Hajj or to study Islam there or at home for much of the twentieth century, while Riyadh remained firmly in the Western camp during the Cold War despite US support for Israel. Riyadh also embraced an American vision of modernity in which capitalism, religion and technological change could coexist. After the Soviet Union collapsed, the absence of Saudi-Soviet ties remained important. 
Al-Qaeda and other Jihadi organisations used Saudi Arabia's close historic ties to Washington to justify violence against the West, while Muslims in Russia and other states of the former Soviet Union had re-embraced Islam, built new cultural institutions and forged unprecedented ties to Saudi Arabia in particular. Despite differences between Moscow and Riyadh over the Arab Spring and Iran's nuclear program, 20,500 Russian Muslims visited Mecca in 2011-a striking contrast from the pre-1992 era when Moscow permitted only 18 Muslims annually from the entire Soviet Union to go on the Hajj pilgrimage to Mecca. ${ }^{10}$

\section{From Russia to the Soviet Union}

Before the First World War, Russia had a tangible but not a large presence in the Arabian Peninsula and the territories that would become the Kingdom of Saudi Arabia. Nearly a quarter of the Russian Empire was Muslim, it controlled nearby territories, and at least a thousand Russian Muslims annually made the Hajj pilgrimage. What's more, Russian Central Asia had deep cultural and historical ties to the Muslim World and Saudi Arabia in particular. Muslims there had joined the Ummah centuries before their fellow Muslims in Southeast Asia, Turkey, West Africa and other traditional core regions of the Muslim World had. Building on these cultural and historical ties, rulers in the Arabian peninsula encouraged the Russians to establish trade associations in major Gulf ports. In 1901 the Emir of Kuwait sought Russian military protection. While St. Petersburg had long desired a naval base in Kuwait and had political agents in Oman, it refused the request out of fear of antagonising Great Britain, a close diplomatic partner in Europe. ${ }^{11}$ Nonetheless, Russia sent its consul from Bushire in Iran to Kuwait in 1903 to become the first European envoy to meet King Abdulaziz. ${ }^{12}$

Following the October 1917 Russian Revolution, the Soviet government portrayed itself as the champion of anti-imperialists and it called on Arab peasants to fight "the first genuine holy war" "under the red banner of the Communist International."13 But few Arabs or Muslims showed any interest in Communism, which forced Moscow to cooperate with what the Soviets termed "bourgeois nationalists" or democrats opposed to imperialism - even if they persecuted Communists in their national boundaries. ${ }^{14}$

This change in policy opened the way for Soviet ties with King Hussein, whose state in the Hijaz controlled the Hajj pilgrimage. ${ }^{15}$ In the eyes of Soviet leaders, the Hajj provided an "ideal listening post and contact point" for channelling Soviet influence and gathering intelligence on the Muslim world. ${ }^{16}$ The Soviet Foreign Minister Gregory Chicherin wrote in 1924 that "getting Mecca is of crucial importance to us." ${ }^{17}$ And he sought to take advantage of the schism that had developed between Great Britain and Hussein when the King claimed the 
title of Caliph, or leader of the global Muslim community, an action which horrified London since it threatened Britain's control over the millions of Muslim subjects in its Empire. Hoping to further inflame the tensions between Britain and its former patron, Moscow dispatched a Tatar Muslim, Karim Khakimov, to Jeddah. ${ }^{18}$ Two of his assistants were non-Muslims; ${ }^{19}$ another was a graduate of the American College of Beirut. ${ }^{20}$ A British diplomat noted that the Khakimov's principal task was propaganda, since there was "certainly not enough work in his agency to keep five Europeans busy."21

But Soviet plans for King Hussein were seemingly dashed when his state was attacked by armies from the neighbouring state of the Najd, governed by King Abdulaziz. Although there was a debate among Soviet leaders in Moscow on how to respond to the conflict, ${ }^{22}$ Khakimov kept contacts open with both sides, and King Abdulaziz permitted him to visit Mecca. There he had an extended audience with the King and called on him to help the great revolt against the European colonial powers. The King politely declined the suggestion. He noted his admiration for Europe and reminded the diplomat of the remoteness of the Soviet Union, the proximity of Great Britain's imperial possessions, and the unsuitability of republican institutions for his kingdom. ${ }^{23}$ Despite such bitter outward hostility and mistakes, Khakimov won praise from the King for the Soviet diplomat's balanced position in the war. When King Abdulaziz declared himself King of the Hijaz and Sultan of Najd in February 1926, the Soviet Union was the first government to recognise his new title. The King responded to Moscow's recognition with a warm note that expressed his "gratitude to the government of the U.S.S.R." and complete "readiness for relations with the government of the U.S.S.R. and its citizens." ${ }^{\text {" }}$ Chicherin's vision of "getting Mecca" appeared to be within sight.

Relations improved even further at the Congress of Mecca. The Congress was called in June 1926 to resolve King Abdulaziz's claims over the sovereignty over Mecca and Medina. At the time, the Hashemite family, which ruled Iraq and Jordan, refused to relinquish its ancient claim to the two Holy Cities, while a number of leading Muslim scholars expressed unease with the conservative tenets of Wahhabism. Some Muslims discussed boycotting the Hajj or establishing an international regime to govern Mecca and Medina. Were Muslims to heed these calls, it could have spelled economic ruin for the Hijaz, which depended on the Hajj for its economic vitality, and scuttled the King's plans to use Hajj proceeds to modernise his state. The stakes could not have been higher.

Recognising the importance of the conference, Moscow chose six prominent Soviet Muslim scholars to attend. According to the British Consul, the Soviet delegates" "behaviour was exemplary" at the conference. ${ }^{25}$ Their presence reminded "the Arabs of the existence of a large anti-imperialist power" 
and provided the votes for King Abdulaziz to be elected the president of the Conference - a crucial first step for him gaining sovereignty over the two holy cities. ${ }^{26}$ The Soviet delegates opened their home to all visitors and supported the King's claim in the Congress. ${ }^{27}$ Significantly, that claim had very powerful opponents, such as Shaykh al-Ahmadi al-Zawahiri, the head of the Egyptian delegation. ${ }^{28}$ (He later headed al-Azhar and his grandson now leads al-Qaeda.) But the Soviets won the admiration of the participants, who elected a Soviet delegate vice president of the Congress. At the end of the Congress, "the head of the Soviet delegation declared that the unity of the Islamic Nation had been achieved with the help of Soviet Muslims." ${ }^{29}$ Two years later in 1928 Moscow dispatched a new chief diplomat to Jeddah, Nazir Bey Turakulov, and in 1930 it raised the status of its mission from a Diplomatic Consulate General to a Diplomatic Mission. ${ }^{30}$

Soviet advances, however, triggered unease among European diplomats. They warned King Abdulaziz about Soviet intentions to use the Hajj for political purposes and sought to reach a political accommodation with him to limit Soviet influence. In exchange for British recognition of his sovereignty over the Kingdom of the Hijaz and the Nejd, the King agreed to refrain from attacking neighbouring British protectorates and to limit the activities of foreign propaganda agents in his territories. ${ }^{31}$ The second article of what came to be called the "Treaty of Jeddah" dealt directly with this issue. It called on both parties to use all means to prevent its territory from being used as a base for "unlawful activities directed against peace and tranquillity in the territories of the other party." 32

When Soviet diplomats in Jeddah aided participants in the 1927 nationalist revolt in the Dutch East Indies, the Dutch government warned King Abdulaziz that it might severely curtail the number of Hajj pilgrims from Southeast Asia should the Hajj serve as a centre for Indonesian nationalists and for others promoting anti-Dutch Soviet propaganda. ${ }^{33}$ The King swiftly complied with these demands. There was a substantial Javanese intellectual and business community in the Hijaz with close ties to Southeast Asia, ${ }^{34}$ and pilgrims from the region contributed greatly to the local economy in the Hijaz during the Hajj. Some pilgrims remained in Jeddah for several months either before or after the Hajj. ${ }^{35}$

Checked from using the Hajj overtly for political propaganda, Khakimov deployed "soft" power to promote his government's interests. The Soviet mission opened a medical clinic, and the Soviet merchant fleet made regular trips and delivered Soviet products to Red Sea ports in the 1920s. ${ }^{36}$ Both had limited direct impact. Although the doctor saw few patients, he terrified European diplomats in Jeddah, who insisted that Riyadh expel him. They feared that he could "visit everywhere under cover of [medical] consultations" and could therefore circumvent the restrictions on Soviet interactions with pilgrims. ${ }^{37}$ 
Soviet mercantile efforts were only slightly better. The Soviet merchant fleet started to make regular trips to the Red Sea in the 1920s and complemented existing passenger service between Odessa and Jeddah. In 1927 Soviet products and commodities were distributed for free or at substantially reduced rates throughout the Hijaz. ${ }^{38}$ The Soviet Eastern Trading Company (the Vostgostorg) did its own marketing and did not allow local merchants to market Soviet merchandise. ${ }^{39}$ Hijazi merchants reacted to this competition with anger and pressed their governor, who had considerable commercial interests, to act. $\mathrm{He}$ forced the Soviets to sell their goods and commodities at competitive prices, secretly forbade Hijazi merchants from buying Soviet goods and convinced the Europeans not to do business with Soviet authorities in Jeddah. A Hijaz-wide ban on Soviet trade was eventually instituted by the end of $1928 .{ }^{40}$

But global economic conditions compelled the merchants in Jeddah (and their government) to reconsider their economic position towards the Soviet Union. The Wall Street crash of 1929 devastated the prices of agricultural commodities which dominated the economic life of South Asia and Southeast Asia. Few Muslims in either region could now afford to go on Hajj, and the number of pilgrims dropped from 132,000 in 1927 to 38,000 in $1931 .{ }^{41}$ The revenue of the Hijaz and the Nejd was cut by a third, while the national currency, the Riyal, plunged in value. The government ran up crushing debts of $£ 300,000$ and scrambled to resolve shortages in petroleum, sugar, and other commodities. ${ }^{42}$ It sought every available source of income, including the pious endowments connected with the Hijaz in Asia and Africa. ${ }^{43}$ Requests for funds from Great Britain, other European governments and Americans were refused. The state's financial situation became so perilous that King Abdulaziz is reported to have told his British confidant, John Philby, "If anyone... were to offer me a million pounds now, he would be welcome to all the concessions that he wants in my country."

Under these conditions, the King had no choice but to accept the Soviets' offer to sell the Hijaz 100,000 cans of Kerosene and oil along with 750 tons of sugar in August 1931. ${ }^{45}$ Even after officials in the Hijaz reneged at the end of 1931 on their obligations to pay Moscow $£ 30,000$ for the oil, Moscow still believed it was possible to improve political ties and to open markets for its timber, cement, china, glass and metal tableware in King Abdulaziz's territories. ${ }^{46}$ A year later the King signalled his desire to improve ties further when his officials asked if Faysal could add the Soviet Union on a previously scheduled trip to France, Great Britain, Poland, and Turkey. When Moscow reacted positively to the suggestion, the Saudi King wrote to M.I. Kalinin, a senior Soviet official, that Faysal's "visit will contribute to the development of relations and friendship between our two counties, relations we are constantly striving to maintain and to consolidate." ${ }^{\prime 77}$ 


\section{Soviet Union Engages Arabia}

Soviet officials did their best to take advantage of the visit and the opportunity to consolidate relations with Saudi Arabia. They made certain that Faysal's visit was a "major event in the nation's political life" and that it received considerable extensive coverage in Izvestiya and other Soviet newspapers. ${ }^{48}$ Train stations in Moscow and Leningrad were adorned with Saudi and Soviet flags and signs in Arabic for Faysal's arrival in the two cities. He and his entourage met elite Soviet and foreign officials and saw the most advanced Soviet military equipment, factories, and scientific facilities. Faysal and his entourage were housed at Leningrad's finest hotel, the Astoria. They also visited the Hermitage Museum and saw plays at the Bolshoi Theatre. ${ }^{49}$ After Faysal and his Saudi delegation returned to Moscow from Leningrad, Soviet leaders organised a day-long sporting festival in their honour that drew 45,000 spectators. Faysal was impressed by the genuine warmth of the Soviet citizens, their advanced technology, and their culture. In Leningrad, he said that "our delegation has become convinced that while other countries we have visited industry is declining, here industry is growing and being developed." 50

Soviet officials backed up their extensive efforts at public diplomacy with offers of financial assistance. Although the Saudi Prince had no success winning additional funds in London or on the European Continent, ${ }^{51}$ Moscow offered the $£ 1$ million his father desired and showed a willingness to forgive the $£ 30,000$ Soviet oil debt. In return, King Abdulaziz was asked to sign a treaty of friendship with the Soviet Union and to lift the trade embargo on Soviet goods in his territories. ${ }^{52}$ Negotiations were sufficiently developed (and Saudi finances sufficiently poor) that Deputy Saudi Foreign Minister Fuad Hamza told the British Consul in Jeddah that King Abdulaziz, who normally would ardently oppose a treaty of friendship with Moscow, was now ready to accept one and a Soviet loan unless London provided Riyadh $£ 100,000 .^{53}$ The consul sent a panicked telegram to the British Foreign Office reporting the conversation as well as noting the growing Soviet influence in the now renamed state of Saudi Arabia, epitomised by the fact that Soviet diplomats spoke Arabic fluently and wore local clothes in public in Jeddah. $^{54}$

Although the British never paid the $£ 100,000$, the loan and the Saudi-Soviet treaty never materialised. While Moscow's refusal to consider Riyadh's claims to the pious foundations tied to the Hijaz within the boundaries of the Soviet Union angered Saudi officials, ${ }^{55}$ the biggest factor hindering Saudi-Soviet ties was the same one it had been for years: Great Britain. ${ }^{56}$ Before travelling to Moscow, Fuad Hamza had sought out the opinions of senior British officials in London on his Kingdom's "unique relationship" with the Soviet Union. ${ }^{57}$ Their reaction 
stressed the ideological gaps between the two states and, implicitly, Saudi Arabia's weakness vis-à-vis Great Britain:

Regarding the question of relations between the Hejaz and Nejd and the Soviet Government, the opinion of His Majesty's Government was that the view and tenets of the Soviet Government were presumably very different from those of the King Abdul Aziz. If however, King Abdul Aziz thought fit, in spite of this, to change his present policy towards the Soviet Government, it would of course, not be a matter upon which His Majesty's Government would be in a position to feel aggrieved. ${ }^{58}$

If this were not enough, most pilgrims were either British subjects or travelled on British-flagged ships through British-controlled seas. The British government regularly provided essential services to the Saudis during the Hajj from medical care to making certain enough Riyals were in circulation to meet the surge in trade. A Soviet loan of $£ 1$ million was not enough to jeopardise those ties or assume the risks of a larger Soviet presence in Saudi Arabia to King Abdulaziz's reputation in the Islamic world. Indeed, it had become common currency among many Muslims by 1930 that Communism and Islam were completely antithetical forces. ${ }^{59}$

Despite the risks of improved ties with Moscow, Riyadh did lift its trade embargo on Soviet goods, and the Vostgostorg was permitted to market all its merchandise in the Kingdom. ${ }^{60}$ But it was largely a symbolic action: U.S. diplomats noted that the Saudis were likely to reinstate the embargo when "taxes and other income from [the Soviets] will have liquidated his $£ 30,000$ obligation" to Moscow. ${ }^{61}$ There was not a great interest in Soviet goods and scant chance that there would be much of a market for anything other than petroleum or petroleum products. And even the market was limited: in the 1930s, Soviet petroleum products were seen in many Red Sea ports as shoddy, defectively packed, and short-weight. ${ }^{62}$

For their part, Soviet economic officials eventually concluded that they had greatly overestimated the economic potential of Saudi Arabia and sought new markets for their goods. Their colleagues in the Foreign Ministry had also downgraded Saudi Arabia in their strategic calculations. Because Moscow needed London's cooperation against increasingly assertive governments in Berlin and Rome, they believed it was imperative for the Soviet Union to abandon the goal of disrupting Great Britain's interests in the Middle East and India. Ironically, twenty years after the October 1917 Russian Revolution, the Soviet Union had returned to essentially the same position as its Russian predecessor in Middle East in which diplomats deferred to the interest of Great Britain, especially in Arabia and the Gulf. ${ }^{63}$

Remarkably, the Soviet mission in Jeddah continued at full staff for much of the rest of the decade. Multiple doctors came and went; one saw eighty patients a 
day, less than half of what his British counterpart saw on a given day. The multiethnic and multi-religious Soviet legation picked up colloquial Arabic quickly and disseminated Communist ideology to ordinary Saudis and government officials alike. The wife of the Soviet Consul reportedly lived for several months in 1937 with the Turkish (and favourite) wife of Prince Faysal, Iffat bint Ahmad al-Thunayan. ${ }^{64}$ But the Legation spent most of its time translating Soviet propaganda into Arabic and Arabic newspapers into Russian. At one point, the Soviet Consul asked his Dutch counterpart how he should translate " "the People's Commissars are chosen by the toiling class." ${ }^{95}$ In May 1939, Moscow closed the mission and recalled its staff, virtually all of whom were executed because of the perceived "failure of the Soviet Mission." "Significantly, the closing of the mission in Jeddah coincided with Moscow's decision to close its consulates in Afghanistan, Iran, Turkey, and Yemen. ${ }^{67}$

Six years later, after the conclusion of World War II, Moscow sought to reestablish diplomatic relations and to reengage Saudi Arabia politically. It permitted Soviet Muslims to go on Hajj for the first time since the 1930s and its propagandists emphasised the heroic contributions of Muslims to defeating the Nazis. ${ }^{68}$ These actions were noticed by Saudi officials. In July 1945, King Abdulaziz told Colonel Hoskins, a visiting U.S. official, that his Kingdom's relations with the Soviet Union "were friendly but not close." ${ }^{.69}$ At the same time, the King noted that he had expelled the Soviet legation in Jeddah for spreading Communist propaganda, Moscow had yet to formally ask to reopen its legation and "for his part he would not take steps to renew diplomatic relations." ${ }^{\prime 70}$ It was now far too late for Moscow to improve the relationship.

\section{Growing American Involvement}

During the previous decade, the United States had emerged as the preeminent power in Saudi Arabia, thanks in part to the fact that oil was discovered (1938) and a U.S. oil company had won the contract to develop Saudi Arabia's oil fields in 1933, a year after Faysal had been impressed by the Soviet oilfields. And it had been clear for a number of years that the desert kingdom was about to become a central player in the global oil markets and potentially overtake the traditional leader, the United States. ${ }^{71}$ When Faysal visited the United States in 1943, he was treated as an honoured guest and shown how American technology could help to modernise Saudi Arabia. ${ }^{72}$ After Faysal's return home, U.S. diplomats worked to capitalise on his trip and demonstrate that Washington was in a position to use its financial and political resources to replace Great Britain's preeminent position in the Kingdom. In the words of British diplomats, who knew what an empire looked like, the Americans were building their own "empire in the Kingdom"and they were not intent on sharing with anyone, especially the British. ${ }^{73}$ 
Washington's dominant position in Saudi Arabia in the 1940s would be important beyond the borders of the Kingdom and magnify the significance for Moscow of the failure to establish ties with Riyadh in the 1930s. In particular, the intense linkage to America, a leading modern Western nation that viewed religion as central to daily life, allowed the Saudis and Muslims around the world to conceive of a form of modernity that did not adhere to either the secularism of twentieth-century Western Europe or the atheism of the Soviet Union. Instead, Muslims were able to balance their faith's values and the requirements of advanced, capitalist, and modern societies, just as Christians in America had done in the past. This balance permitted Saudi Arabia to stay within the Western camp during the Cold War, even though the Kingdom's positions on the ArabIsraeli conflict were far closer to those of the Soviet Union.

Thanks to their close ties with Saudi Arabia, US officials could be confident that Western Europeans would have the cheap, plentiful oil necessary for the Marshall Plan to be a success and to check Soviet expansion in Western Europe. Saudi oil also helped fuel the strong post-war growth of the global economy, which was also critical to the US strategy for containing expansion of Soviet influence in the developing world, especially in Asia. No nation was a stronger ally of Washington and a more ardent foe of Moscow than Riyadh. Regionally, the US-Saudi strategic partnership allowed Washington to have close ties with Israel without being shut out of the politics of the Arab world. That link would be critical to its new role after the 1973 Arab-Israeli war as an honest broker between Arabs and Israelis.

By contrast, the Soviets had strong relations with only Arab republics. Had Moscow developed lasting ties with the Saudis during the interwar period, especially if it had given the loan in the 1930s, it might have had a chance to develop the Kingdom's oil resources and been in a better position to influence Riyadh's decisions during the Cold War. Such a relationship is certainly conceivable, as Moscow cooperated with regimes which suppressed Communist parties after the 1950s. A possible venue for building a relationship could have been the nonaligned movement, of which Saudi Arabia and a number of Moscow's closest diplomatic partners were also members. For Riyadh, a bilateral relationship with Moscow (or one of its close allies) would have allowed it to pursue a more balanced foreign policy during the Cold War and perhaps allowed it to extract a far higher price from Washington for its assistance. While one can only guess as to how a stronger Saudi Arabia might have changed the Arab-Israeli conflict and other international issues, we can be certain that it would have had some impact and changed Washington's approach. Indeed, Moscow frequently observed how close Soviet and Saudi views on the Arab-Israeli conflict were and "that SaudiSoviet cooperation would enhance the Arab cause." ${ }^{14}$ 


\section{Post-Cold War Events}

Remarkably, the consequences of the failure of Saudi-Soviet ties have been even larger after the end of the Cold War. Although al-Qaeda originated in Afghanistan, fighting alongside an American-backed insurgency during the 1980s, the organisation and its charismatic leader, Osama Bin Laden, cited Washington's presence in the Middle East after the 1940s as the root cause for the problems facing the global Muslim community. References to Washington's presence in the Middle East and the wider Muslim world pepper the many statements of Bin Laden during the 1990s and 2000s, especially when he discusses the politics of his native Saudi Arabia and the other states in the Middle East. In a blistering 2004 communiqué entitled "Depose the Tyrants," Bin Laden asserts that "no appointment of a king or representative can take place" in Saudi Arabia "without the agreement of America." He further notes that American power reflects "agreements between previous [Saudi] kings and America"-presumably a reference to the famous meeting between President Franklin Delano Roosevelt and King Abdulaziz in 1945 on a battleship in the Red Sea. ${ }^{75} \mathrm{He}$ also asserts that there was little difference between the actions of L. Paul Bremer, the U.S. administrator of Iraq, and other regimes in the Middle East "when it comes to implementing America's policies." ${ }^{" 76}$ America was equally important to the organisation's online and video productions: pictures of Saudi leaders dancing with U.S. presidents were central to a video that was released months before the terrorist attacks of 11 September 2001. ${ }^{77}$

As horrific as those acts of terrorism were, the post-Cold War era has also witnessed the rebirth of Islam in the former Soviet Union and the reintegration of its Muslims into the global Muslim community. While usually less than twenty pilgrims were permitted to go on Hajj annually after 1917 from the entire Soviet Union, ${ }^{78}$ more than 22,000 Russians made the pilgrimage in 2011. ${ }^{79}$ (One was a hundred-ten year-old woman from the North Caucasus. $)^{80}$ It is estimated that close to a third of Russia's 20.5 million Muslims have performed the Hajj more than once. ${ }^{81}$ Between 1992 and 2011, nearly 300,000 Russians went on Hajj, ${ }^{82}$ while the number of mosques in Russia increased from 90 to $7,000 .^{83}$ During the same period, the Russian government registered 96 domestic Muslim educational institutions, including seven universities, and started a national program for training Russian imams ${ }^{84}$ Moscow's Muslim population has grown to nearly two million and the city boasts its own Muslim hospital. ${ }^{85}$ Similar increases in mosques, adherence to Islam and school construction occurred in other former Soviet republics with large Muslim populations after 1992. It should come as no surprise that one of the Muslim world's most important popular singers, Maher Zain, included Russian subtitles for his video released in March 2012, "Number one for me." 86 
Since reestablishing diplomatic relations in the 1990s, Moscow and Riyadh have cooperated in global energy markets and seen bilateral trade rise from $\$ 89$ million in 1999 to nearly \$1 billion in 2010. ${ }^{87}$ In 1991, Riyadh provided Moscow with $\$ 2.5$ billion in assistance and forged close ties to Soviet Muslims, whose religious freedom had been a Saudi precondition to improved ties with Moscow. ${ }^{88}$ Russian President Vladimir Putin visited Saudi Arabia in 2007, negotiated a substantial increase in the number of Russian Hajj pilgrims, and permitted members of the Russian security service to go on pilgrimage. ${ }^{89}$ (His successor, President Dmitry Medvedev, secured a similar increase in the number of Russian Hajj pilgrims in 2011. $)^{90}$ There has also been renewed interest in the Soviet Union's relationship with Saudi Arabia during the interwar period. A multilingual book on Prince Faysal's 1932 visit to the Soviet Union was published in Saudi Arabia in 2002, ${ }^{91}$ and there have been conferences in Russia and other former Soviet republics on the relationship. An edited collection of Turakulov's papers from his days as a Soviet diplomat were published in Russian in Moscow in 2003. ${ }^{92}$ There has been even greater interest in Khakimov, who is the subject of a 2012 documentary movie in Russian, Karim Khakimov: Kremlin's wazier in Arabia. ${ }^{93}$

This intense interest in the relationship, however, has coincided with a decline in bilateral ties that threatens to revive the tensions of the Cold War. Within the regional political dynamic that has emerged in the wake of the Arab Spring and tensions over Iran's nuclear program, Moscow and Riyadh are members of rival coalitions vying for power in the Middle East. Russia supports China, Iran and their regional allies. By contrast, Saudi Arabia backs the United States and its European and regional allies. Just as the Soviet Union and Saudi Arabia once supported opposing factions in Afghanistan, Yemen and other conflicts throughout the Cold War, Russia and the Saudi Arabia are now on opposite sides of many of the conflicts that have emerged from the Arab Spring. In Syria, Moscow has provided significant assistance to the government of President Bashar al-Assad, while Riyadh has provided moral and direct support to the rebellion that started in March 2011. Further inflaming bilateral tensions are allegations that militants linked to Saudi Arabia (often called "Wahhabis" in Russia) are seeking to convert the Muslim populations in the Caucasus to Islamic extremism and played a role in a series of attacks on Muslim religious officials in Russia, including those in June 2012 on the Mufti of Tatarstan and the top Muslim official in charge of education in Kazan, Valiulla Yakupov. Russian authorities are especially suspicious about the attack on Yakupov, who sought to ban Wahhabism within Russia before he was assassinated. ${ }^{4}$

That said, it would be foolish for policy makers in the West and the wider Muslim world to dismiss the potential of ties between Saudi Arabia, Russia, and other former Soviet states. Not only have they maintained relations despite 
the tensions over Syria and elsewhere of the last two years, but there are also cultural, historical, and religious linkages that transcend politics. What's more, it is helpful to remember the role that Muslim territories of the former Soviet Union, such as Turkmenistan, Uzbekistan, and Tajikistan, had in Muslim history after they were integrated into the Ummah in the seventh century. At that time, these territories were part of greater Khorasan, a frontier region of the Islamic world and an epicentre of a defining moment in Muslim and world history: the Abbasid Revolution. The revolution, which began in 750 C.E., destroyed the Umayyad dynasty in Damascus, saw the rise of the Abbasids and Baghdad, and established the principle that non-Arabs could be Muslims. The principle that Islam was not reserved solely for Arabs would be crucial to its subsequent growth and its status today as a global faith of over 1.5 billion Arabs and non-Arabs. ${ }^{95}$

As Russian and non-Russian Muslim areas of the former Soviet Union are integrated into the global Muslim community for a second time, Saudi Arabia's ties with Russia and the rest of the former Soviet Union may finally fulfil the promise of the 1920s and 1930s. In coming years, Muslims there are poised to have an impact on Islam and human history which could surpass the wildest dreams of Khakimov and his Soviet colleagues when Prince Faysal arrived in Moscow in June 1932.

Observers concerned with shaping policy across the Muslim world as well as in Europe and North America may anticipate renewal of ties between the Kingdom and Russia as well as the former Soviet states, given the historical, political, and religious links binding their peoples. Muslim peoples of the newly independent states in particular may find, in their relations with the people of Saudi Arabia, a renewed connection with the Islamic heartland which their historical moment requires.

Beyond this, the rising profile of Russia's strategic interests as a foil to the fading weight of United States in the Arab World and the Middle East is evidence for the re-assertion of historical requirements and economic possibilities in a multi-polar context. Therefore pragmatic factors suggest the following:

- Exchanges between the Kingdom, Russia, and Muslim majority regimes of Central Asia should be reviewed in light of changing regional realities.

- Research, cultural and religious reciprocity, and historical and sociological collaboration should be promoted between Russia and the Kingdom, in order to promote the best interests of both nations in the context of the Muslim peoples in Russia.

- Mutual academic and policy institutions might be established as a mark of recognising these strategic shifts and preparing for future contingencies: Russian and Central Asian studies in the Kingdom, and Saudi and Gulf studies in Russia. 


\section{Notes}

* Sean Foley, Associate Professor of History at Middle Tennessee State University (USA), and recently a Fulbright research scholar at the International Institute of Islamic Thought and Civilization (ISTAC) in Kuala Lumpur, who specialises in the Arab Middle East and religious and political trends in the Islamic world. He taught at Georgetown University, where he took his M.A. in Arab Studies in 2000 and a PhD in History in 2005. Dr Foley has contributed commentary on Asia, the Middle East, and Islamic affairs to The Atlantic, The Daily Zaman (Turkey), al-Jazeera.net, al-Jazeera English Television, The New Straits Times (Malaysia), The Tennessean, and Voice of America Television. He has published widely on Islamic history, Sufism, Middle East and Persian Gulf politics, and Muslims in American history. His first book, The Arab Gulf States: Beyond Oil and Islam, was published by Lynne Rienner Press in March 2010. His website is www.seanfoley.org.

1. The other visitor was the King of Afghanistan, who travelled to Moscow on March 30, 1928. It is worth noting that Faysal was the not the first Arab leader to visit Russia. In 1901, the foreign minister of Morocco, Abdel Karim bin Suleiman, visited Moscow and St. Petersburg. His official itinerary was remarkably similar to that of Faysal's three decades later. For more on Suleiman's visit, see Paul du Quenoy, "Tidings from A Faraway East: The Russian Empire and Morocco," International Historical Review 33, no. 2 (June 2011): 185-203.

2. Other Saudi officials who joined him were Saudi Deputy Foreign Minister Fuad Bey Hamza and Faysal's aide-de camp, Khalid al-Ayubi. Vitali Naumkin, Emir Faisal in Russia, 1932: Dedicated to the $70^{\text {th }}$ Anniversary of the Late King Faisal's Visit to Russia (Riyadh: King Faisal Center for Research and Islamic Studies, 2002), 11.

3. Joseph A. Kéchichian, Faysal: Saudi Arabia's King for all Seasons (Gainesville, FL: University Press of Florida, 2008), 35-36; David Holden and Richard Johns, The House of Saud: The Rise and Rule of the Most Powerful Dynasty in the Arab World (New York: Holt, Rinehart and Winston, 1981), 107-108; Badr Alkhorayef, "Faisal Laid Foundation of Strong Saudi-Russian Ties," Arab News, 7 May 2008, http://archive.arabnews.com/?page=9\&section=0\&article=109659\&d=8\&m $=5 \& y=2008$; Felix Cole, Chargé d' Affaires, Riga to U.S. Secretary of State, "Visit to Moscow of delegation from the Kingdom of the Hejaz and Nejd and its Dependencies," 1932, no. 418, reprinted in Documents on the History of Saudi Arabia, ed. Ibrahim al-Rashid, in Establishment of the Kingdom of Saudi Arabia under Ibn Saud, 1928-1935, vol. 3 (Salisbury, NC: Documentary Publications, 1976), 220-225; "Prince of Hedjaz Greeted by Soviet," New York Times, 30 May 1932, p. 15, Pro-Quest Historical New York Times (web); "Red Troops March for Royal Visitor," Washington Post, 30 May 1932, p. 3, Pro-Quest Historical Washington Post (web).

4. Kéchichian, Faysal, 35-36; Robert Lacey, The Kingdom: Arabia and the House of Saud (New York: Avon Books, 1981), 240-241.

5. "Hejaz and Nejd Win Recognition by U.S.," Washington Post, 4 May 1931, p. 1, Pro-Quest Historical Washington Post (web).

6. A good example of American views of Saudi Arabia in the 1920s is Clayson W. Aldridge, American Vice Consul in Charge of U.S. Consulate in Aden, Arabia to U.S. Secretary of State, "Growing Modernization of the Hedjaz," 23 January 1928, no. 38, reprinted in Documents on the History of Saudi Arabia, in The Consolidation of Central Arabia Under Ibn Saud, 1925-1928, vol. 2, 150-156.

7. Holden and Johns, The House of Saud, 108.

8. Mark Katz, "Saudi-Russian Relations in the Putin Era," The Middle East Journal 55, no. 4 (Autumn 2001): 604; and John Baldry, "Soviet Relations with Saudi Arabia and the Yemen 1917-1938," Middle Eastern Studies 20, no. 1 (January 1984): 74.

9. The most recent substantial works on the subject were published in the 1970s and mid 1980s: Stephen Page, The USSR and Arabia (London: Central Asian Research Institute in association with Canadian Institute of International Affairs. 1971); Baldry, "Soviet Relations"; and Steven Katz, Russia and Arabia: Soviet Foreign Policy toward the Arabian Peninsula (Baltimore: Johns Hopkins University Press, 1986). Two other scholars who have written on Soviet relations with the Middle East and Saudi Arabia in particular are Robert O. Freedman and Andrej Kreutz. Good examples of their work are Robert O. Freedman, Moscow and the Middle East: Soviet Policy since the Invasion of Afghanistan (Cambridge: Cambridge University Press, 1991); and Andrej Kreutz, "Russia and the Arabian Peninsula," Journal of Military and Strategic Studies 7, no. 2 (Winter 2004): 1-58. 
10. BBC Monitoring Former Soviet Union - Political Supplied by BBC Worldwide Monitoring, "Russian president meets Muslim clergy in Bashkortostan," 23 November 2011, LexisNexis Academic (web).

11. Andrej Kreutz, Russia in the Middle East: Friend or Foe (Westport, CT and London: Praeger Security International, 2007), 123-124; and G.M. Yemelianova, "Russia and Islam: The History and Prospects of a Relationship," Asian Affairs 26, no. 3 (October 1995): 284.

12. Holden and Johns, The House of Saud, 97.

13. Baldry, "Soviet Relations," 56.

14. Page, The USSR and Arabia, 15.

15. Ibid.

16. Jon Jacobson, When the Soviet Union Entered World Politics (Berkeley, CA: University of California Press, 1994), 181.

17. Ibid.

18. Kreutz, Russia in the Middle East, 124; and Page, The USSR and Arabia, 15.

19. It should be noted the diplomats were not the only Russians in Jeddah at the time. There was a pilot in the Hijazi air force named Shirokoff. He would remain in Jeddah well into the 1930s. Joshua Teitelbaum, The Rise and Fall of the Hashemite Kingdom of Arabia (New York: New York University Press, 2001), 49; and Baldry, "Soviet Relations," 74.

20. Bullard to Chamberlain, E3518/2442/91, 18 May 1925, reprinted in British Documents on Foreign Affairs: Reports and Papers from the Foreign Office Confidential Print, eds. Kenneth Bourne and D. Cameron Watt, in Part 2: From the First to the Second World War, Series B: Turkey, Iran, and the Middle East, 1918-1939, ed. Robin Bidwell, in The Expansion of Ibn Saud, 1922-1925, vol. 4 (Bethesda, MD: University Publications of America, 1985), 287-289; Stonehewer-Bird to Chamberlain, no. 49, E3363/332/91, 9 April 1928, reprinted in British Documents on Foreign Affairs, in Eastern Affairs, January 1928-June 1930, vol. 6, 35-36.

21. Other European diplomats were not much more occupied much of the year either. A 1923 report written by the Lebanese-American author Ameen Rihani for U.S. diplomats observed that European consuls in Jeddah "have little to do...except in the pilgrim season." Edward M. Groth, Consul in Charge, American Consulate in Beirut to U.S. Secretary of State, "Report on Arabia from Mr. Ameen Rihani," 27 October 1923, no. 1188, reprinted in Documents on the History of Saudi Arabia, in The Unification of Central Arabia Under Ibn Saud, 1909-1925, vol. 1, 119-120; Bullard to Chamberlain, E3518/2442/91, reprinted in British Documents on Foreign Affairs, 289.

22. Kreutz, Russia in the Middle East, 124.

23. Bullard to Chamberlain, E3518/2442/91, reprinted in British Documents on Foreign Affairs, 287-289.

24. For a text of the document, see "Correspondence on the Question of the Recognition of the USSR of the Government of the King of the Hijaz, Nejd and Annexed Territories," reprinted in Documents on the History of Saudi Arabia, vol. 3, 214-215.

25. Baldry, "Soviet Relations," 60.

26. Ibid.

27. Page, The USSR and Arabia, 16.

28. Martin Kramer, Islam Assembled: The Advent of the Muslim Congresses (New York: Columbia University Press, 1985), 107 \& 116-117.

29. Ibid.

30. Turakulov was more pious than his predecessor and was accompanied by his wife, a doctor from Samara. He spoke French, Arabic, and Turkish. Cole, "Visit to Moscow of delegation from the Kingdom of the Hejaz and Nejd and its Dependencies," 223; and Kéchichian, Faysal, 36.

31. Baldry, "Soviet Relations," 62.

32. Reprint of the Anglo-Hijazi Treaty in The New Near East and India (London, England), 27 September 1927, reprinted in Documents on the History of Saudi Arabia, vol. 2, 131.

33. Baldry, "Soviet Relations," 62.

34. Those ties would become especially important in the 1940s when Indonesians achieved independence from the Dutch. Indonesian nationalists in Saudi Arabia agitated strongly for independence. The Saudi government, which knew that the Dutch government's position in Indonesia and in the world had been substantially weakened by World War II, permitted the protests. A 1946 U.S. diplomatic 
cable observed: "In view of the sympathy of the Government [of Saudi Arabia] for the efforts of colonial people to obtain their independence, and particularly fellow Moslems, no obstacles were placed...against this propaganda." J. Rives Childs, Jidda, Saudi Arabia, to U.S. Department of State, "Prohibition of Political Propaganda in Saudi Arabia," 14 August 1946, no. 39, reprinted in Saudi Arabia Enters the Modern World, ed. Ibrahim al-Rashid (Salisbury, NC: Documentary Publications, 1980), pt. 2, vol. 5, 46.

35. Sugata Bose, A Hundred Horizons: The Indian Ocean in the Age of Global Empire (Cambridge: Harvard University Press, 2006), 204.

36. Baldry, "Soviet Relations," 63.

37. Ibid.

38. Ibid.

39. W.N. Walmsley, American Consulate, Aden, Arabia to U.S. Department of State, "Saudian Political and Financial Problems," 12 April 1933, no. 162 in Documents on the History of Saudi Arabia, vol. 3, 173.

40. Ibid.

41. Holden and Johns, The House of Saud: The Rise and Rule of the Most Powerful Dynasty in the Arab World, 107; and Sean Foley, The Arab Gulf States: Beyond Oil and Islam (Boulder, CO: Lynne Rienner Press, 2010), 24.

42. Ibid.

43. Foley, The Arab Gulf States, 22.

44. Holden and Johns, The House of Saud, 108.

45. Talal Nizameddin, Russia and the Middle East: Towards a New Foreign Policy (London: Hurst and Company, 1999), 185.

46. Holden and Johns, The House of Saud, 107.

47. Naumkin, Emir Faisal in Russia, 6.

48. Other newspapers that covered the event were the Leningrad Pravda and the Moscow Daily News. Cole, "Visit to Moscow," 223-224.

49. Naumkin, Emir Faisal in Russia, 16-22.

50. Ibid., 22 .

51. Lacey, The Kingdom: Arabia and the House of Saud, 240.

52. Ibid.

53. Holden and Johns, The House of Saud, 108.

54. Ibid.

55. Naumkin, Emir Faisal in Russia, 7.

56. Holden and Johns, The House of Saud, 108.

57. Baldry, "Soviet Relations," 72-73.

58. Ibid.

59. For more on Great Britain's relationship to the Hajj, see Foley, The Arab Gulf States, 22-26.

60. Walmsley, "Saudian Political and Financial Problems," 168.

61. Ibid., 172 .

62. Bert Fish, U.S. Legation to Cairo, "Remarks of Mr. St. John Philby at Jedda," 9 March 1940, no. 2019, in Saudi Arabia Enters the Modern World, pt. 2, 35.

63. Baldry, "Soviet Relations," 73.

64. Ibid.

65. Ibid., 74 .

66. Ibid., 75 .

67. James P. Piscatori, "Islamic Values and National Interest: The Foreign Policy of Saudi Arabia," in Islam in Foreign Policy, ed. Adeed Darwisha (Cambridge: Cambridge University Press, 1983), 37.

68. C.L. Sulzberger, "Policy on Moslems Aids Soviet Union," New York Times, 15 January 1945, p. 3 , Pro-Quest Historical New York Times (web).

69. William Eddy, U.S. Minister to Saudi Arabia to Colonel Hoskins, Economic Consul, U.S. Legation to Cairo, and Loy W. Henderson, Chief, Division of Near Eastern and African Affairs, Department of States, "Conversation of Colonel Hoskins With King Abdul Aziz Bin Saud At Riyadh on July 2, 1945 at 9:00 A.M.," 11 July 1945, Jidda Saudi Arabia, reprinted in Documents on the History of Saudi Arabia, vol. 4, pt. 1, 253. 
70. Ibid.

71. C.L. Sulzberger, "Soviet Oil Output Put At 60,000,000 tons," New York Times, 23 June 1947, p. 10, Pro-Quest Historical New York Times.

72. Foley, The Arab Gulf States, 38.

73. Ibid.

74. For their part Saudi leaders rejected Soviet arguments out of hand. In their eyes, Soviet foreign policy was designed to help Soviet interests and not those of the Arabs. Faysal ironically was essential to cementing this view and was extremely hostile to the Soviet Union. He blamed the Soviet Union for Israeli victories in wars in 1948 and 1967 and saw Communism and Zionism as acting in concert against the Arabs. Katz, Russia and Arabia, 149.

75. "Depose the Tyrants," reprinted in Messages to the World: The Statements of Osama Bin Laden, ed. Bruce Lawrence and trans. James Howarth (New York: Verso Press, 2005), 251.

76. Ibid., 260 .

77. For more on the video, see Sean Foley, "The Naqshbandiyya-Khalidiya, Islamic Sainthood, and Religion in Modern Times," The Journal of World History 19, no. 4 (2008): 541.

78. Michael Schwirtz, "Putin Opens Mecca Path for Muslims," A9.

79. BBC Monitoring Former Soviet Union - Political Supplied by BBC Worldwide Monitoring, "Russian president meets Muslim clergy in Bashkortostan."

80. For more on this woman's story, see http://www.rt.com/news/russian-centenarian-pilgrimage-hajj-875.

81. Milena Faustova, "Russian Muslims ready for Hajj," The Voice of Russia, 28 October 2011, http:// english.ruvr.ru/2011/10/28/59517883.html.

82. Mikhail A. Alexseev, "The Impact of the Hajj Pilgrimage in the North Caucasus," PONARS Eurasia Policy Memo No. 74 (2009), 1; and BBC Monitoring Former Soviet Union - Political Supplied by BBC Worldwide Monitoring, "Russian president meets Muslim clergy in Bashkortostan."

83. BBC Monitoring Former Soviet Union - Political Supplied by BBC Worldwide Monitoring, "Russian president meets Muslim clergy in Bashkortostan."

84. Ibid.

85. Schwirtz, "Putin Opens Mecca Path for Muslims," A9.

86. For more on this video, go to http://www.youtube.com/watch?v=f4J7-WR1QOY\&feature=relmfu.

87. BBC Monitoring Middle East - Political Supplied by BBC Worldwide Monitoring, "Saudi-Russia trade forum to open in Riyadh 12 June," 11 June 2012, LexisNexis (web); and International Monetary Fund, "Direction of Trade Statistics: Saudi Arabia," http://elibrary-data.imf.org/FindDataReports. aspx?d $=33061 \& \mathrm{e}=170921$.

88. During the 1980s, Saudi Arabia had four preconditions for improved relations with the Soviet Union: 1) Soviet forces had to be withdrawn from Afghanistan, 2) the USSR and its allies must reduce their military presence in both South Yemen and Ethiopia, 3) the USSR must end all hostile propaganda against the Kingdom, 4) Soviet Muslims must be allowed greater freedom to practice their religion. Katz, Russia and Arabia, 138-139.

89. Schwirtz, "Putin Opens Mecca Path for Muslims," A9.

90. BBC Monitoring Former Soviet Union - Political Supplied by BBC Worldwide Monitoring, "Russian president meets Muslim clergy in Bashkortostan."

91. Vitali Naumkin, Emir Faisal in Russia. The book is in Arabic and English and has newspaper articles and diplomatic documents in Arabic and Russian.

92. T.A. Mansurov, Polpred Nazir Tiuriakulov: Diplomat, politic, grazhdanin (Moscow: Real Press, 2003).

93. To see a brief clip of the movie, go to http://www.youtube.com/watch?v=cPH1yD3u_ec.

94. David M. Herszenhorn, "More Than a Dozen Die in 2 Attacks in a Russian Republic," New York Times, 29 August 2012, LexisNexis Academic; "Islamic scholar reportedly killed in Dagestan attack source," Russia \& CIS General Newswire, 28 August 2012, LexisNexis Academic; BBC Monitoring Former Soviet Union - Political Supplied by BBC Worldwide Monitoring, "Russian pundit expects backlash from attacks on Tatarstan religious leaders," 8 August 2012, LexisNexis Academic.

95. Nicholas Eberstadt and Apoorva Shah, "Fertility Decline in the Muslim World: A Veritable Sea-Change, Still Curiously Unnoticed," in Population Dynamics in Muslim Countries: Assembling the Jigsaw Puzzle, eds. Hans Groth and Alfonso Souza-Poza (London and New York: Springer, 2013), 12-13. 